\title{
Myśl Jana Pawła II w kontekście polityki społecznej w czasach postindustrializmu
}

\section{Wprowadzenie}

Przedmiotem tego artykułu jest koncepcja polityki społecznej we współczesnym świecie. Punktem wyjścia moich rozważań będzie 25 rocznica encykliki Centesimus annus Jana Pawła II, która wydaje się niezbędnym źródłem dla wszelkiego myślenia o polityce społecznej. Ogłoszona została, jak wiadomo, w stulecie powstania innej encykliki, Rerum novarum Leona XIII, która poświadcza tradycję troski Kościoła o świat społeczny, w jakim żyją ludzie. Czytamy: „Leonowi xıI kazała przemówić świadomość misji następcy Piotra. Ta sama świadomość kieruje dziś jego następcą [...] Do takich rzeczy, które włączając się w nurt Tradycji, stają się «stare» i dostarczają sposobności i tworzywa do jej wzbogacenia i do wzbogacenia życia wiary, należy również owocna działalność milionów ludzi, którzy pod wpływem nauki społecznej Kościoła starali się czerpać z niej natchnienie dla swego zaangażowania w świecie. Działając indywidualnie czy łącząc się na różne sposoby w grupy, stowarzyszenia i organizacje, tworzyli oni jakby wielki ruch obrony osoby ludzkiej i ochrony jej godności, przez co przyczyniali się pośród zmiennych wydarzeń dziejowych do budowania społeczeństwa bardziej sprawiedliwego, a przynajmniej przeciwstawiali się niesprawiedliwości i próbowali ją ograniczyć”"

Jednak Jan Paweł II nie poprzestał jedynie na oddaniu szacunku dziełu swego poprzednika, ale odniósł się też do współczesnego nam kontekstu społecznego. Kontekst ten był wówczas szczególnie istotny. Był to czas 
przełomu w Europie i na świecie, jaki rozpoczął się w 1989 roku. Pisał Jan Paweł II: „Rocznica encykliki Rerum novarum nie zostałaby należycie upamiętniona, gdyby zabrakło odniesienia jej do sytuacji dzisiejszej. Sama zresztą treść Dokumentu skłania do rozważenia go pod tym kątem, jako że zawarty w nim opis sytuacji historycznej oraz przewidywania okazały się w świetle tego, co nastąpiło później, zaskakująco trafne. Potwierdziły to w szczególności wydarzenia ostatnich miesięcy roku 1989 i pierwszych miesięcy roku 1990. Wydarzenia te oraz radykalne przemiany, które po nich nastąpiły, można zrozumieć jedynie na tle wcześniejszych sytuacji, które były poniekąd konkretnym i instytucjonalnym urzeczywistnieniem przewidywań Leona xıII i coraz bardziej niepokojących sygnałów dostrzeganych przez jego następców. Papież przewidział bowiem wszystkie negatywne konsekwencje - polityczne, społeczne i gospodarcze - ustroju społeczeństwa proponowanego przez «socjalizm», który wtedy istniał jako filozofia społeczna i jako ruch mniej lub bardziej zorganizowany" ${ }^{2}$. Znaczenie wspomnianej encykliki, podobnie jak innych pism Jana Pawła II, dla współczesnego pojmowania polityki społecznej będzie przedmiotem późniejszych rozważań, gdy już przedstawię szerszy kontekst sytuacyjny, pozwalający zrozumieć głębiej myśl papieża.

Kwestia współczesności świata ma tu znaczenie podstawowe. Zakładam bowiem, iż stwarza on dziś szczególne problemy, które wymagają przemyślenia sensu, roli i strategicznych celów polityki społecznej raz jeszcze. Istnieje niemała literatura na ten temat. W socjologii bodaj najbardziej znaczący jest głos Anthony’ego Giddensa, który próbował tworzyć most między neoliberalnym konceptem i wizją socjaldemokratyczną. Niemała jest też literatura na temat propozycji Giddensa. Zapewne wiele inspirujących idei można wciąż jeszcze od niego zaczerpnąć. Wydaje się jednak, iż sprawy kształtują się dziś o wiele bardziej dramatycznie, niż nawet Giddens potrafił to przewidzieć.

Osobnym wątkiem tego artykułu jest analiza współczesnego kryzysu cywilizacyjnego i szczególnej sytuacji kapitalizmu, o którym jedni powiadają, że się ostatecznie kończy, inni zaś cieszą się lub martwią jego rozkwitem. Osobliwym, ale dramatycznym kontekstem dla tych rozważań jest obecny kryzys gospodarczy, któremu poświęcam niżej nieco uwagi.

2 CA 12. 
Szczególnie ważny jest tu wątek dotyczący koncepcji, znaczenia i strategicznego sensu polityki społecznej.

Powaga problemów, w jakie uwikłana jest współcześnie polityka społeczna, skłania do najbardziej fundamentalnego namysłu nad człowiekiem jako takim, jego powinnościami względem siebie i innych, znaczeniem wspólnoty ludzkiej, kwestii dobra wspólnego, powołania państwa i rozmaitych związków państw, roli globalnej społeczności. Wszystkie te zagadnienia trzeba rozważyć w kontekście wspomnianego kryzysu cywilizacyjnego, do którego zaliczyć należy kryzys człowieka, kultury, społeczeństwa, gospodarki i państwa. Wymaga to zatem pogłębionej refleksji z zakresu antropologii filozoficznej i filozofii społecznej. Kluczową sprawą dla tego artykułu jest zbadanie użyteczności dla takiej refleksji myśli Jana Pawła II.

Tak zakreślony zamiar wymagałby ogromnej monografii. Naturalnie przekracza to możliwości autora w ogóle, a w tym artykule w szczególności. Przyświeca mi tu zamiar skromniejszy: nakreślenia głównych problemów i hipotez oraz wstępnego uporządkowania zakresu tematycznego i „materiału” faktograficznego, a także głównych teorii, jakie mogłyby być dobrym początkiem takiej pracy.

\section{Cywilizacyjny kontekst polityki społecznej}

Od przeszło 40 lat, w związku z wielkimi przeobrażeniami technologicznymi, mamy do czynienia z narastającym globalnym i totalnym kryzysem cywilizacyjnym, który wywołuje szereg zmian. Składają się na nie cztery podstawowe procesy: globalizacja gospodarki, kultury, przyspieszona sekularyzacja i kryzys tradycyjnego ładu społecznego. Zmiany te pociągają za sobą wiele dobroczynnych skutków, otwierają nowe szanse przed ludzkością, dają wiele nadziei. Jednak również powodują, przejściowo lub nie, wiele dramatycznych konsekwencji o ewidentnie negatywnym znaczeniu, a także stwarzają napięcia i różne rodzaje ryzyka, z tymi o eschatologicznym wymiarze włącznie. Globalizacja technologiczna i gospodarcza powoduje globalizację kultury - przede wszystkim w postaci kultury masowej.

3 Więcej na ten temat w: K. Wielecki, European social order transformation, mass culture and social marginalisation processes, „Yearbook of Polish European Studies Warsaw 
Nie miejsce tu na długą analizę pojęcia cywilizacji. Przyjmijmy, że jest to pewien stan kultury, wynik procesów historycznych długiego trwania, wytwarzany przez społeczeństwa, przekraczający czas życia kilku pokoleń. Cywilizacja tworzy ramy, w których, w niemałym stopniu pod jej wpływem, ludzie konstruują ład społeczny, tworzą grupy i instytucje społeczne, kulturę i swoje tożsamości. Cywilizacja to ogół wytworów społecznych, jakie powstają w odpowiedzi na kryzys cywilizacyjny ${ }^{4}$.

Zmiana cywilizacyjna zaś - jak proponuję ją rozumieć - to splot kilku procesów o charakterze historycznym, występujących w tym samym czasie i przestrzeni. Sięgnijmy najpierw do „rewolucji industrialnej”. Od XIV wieku rozwijały się różne odmiany kapitalistycznego instrumentarium ekonomicznego, od xVII wieku trwała, związana z oświeceniem, a potem modernizmem, sekularyzacja (której pierwsze oznaki można odnajdować nawet w renesansie), od wieku XvıI rozwijała się „rewolucja" naukowa i techniczna, powodująca m.in. przewrót w technologiach. W XIX wieku procesy te spotkały się, tworząc kapitalistyczne społeczeństwo industrialne. Ale wielkie znaczenie w tym procesie miała też wcześniejsza ewolucja państwa i monarchii, pewne prądy intelektualne (przede wszystkim oświeceniowe), rozwój nauki, zmiany estetyki itd. ${ }^{5}$

Zmiana cywilizacji powoduje kryzys cywilizacyjny, czyli - zgodnie ze starogreckim znaczeniem słowa „kryzys” - punkt zwrotny, przełom. Pojęcie kryzysu cywilizacyjnego dotyczy sytuacji zmiany cywilizacyjnej, w której pojawiają się wyzwania cywilizacyjne. Utrudniają one lub uniemożliwiają istnienie społeczeństwa bez istotnych zmian, głębokich, długotrwałych, a czasem dramatycznych procesów adaptacyjnych. Czynnikami takiego kryzysu mogą być wielkie wydarzenia historyczne (wojny, rewolucje itp.), zjawiska przyrodnicze (powodzie, trzęsienia ziemi itp.) albo też przełomowe odkrycia naukowe i techniczne czy nowe religie, idee lub wielkie racjonalizacje, wyobrażenia, mity. Czynniki takie często są wyzwaniem nie tylko dla jakiejś odosobnionej społeczności, lecz także mają znaczenie bardziej uniwersalne. Tradycja zatem wiąże pojęcie cywilizacji z szerszą przestrzenią. Cywilizacje długo powstają

University Centre for Europe" 9 (2005), s. 115-133; tenże, Społeczne aspekty kultury masowej. Studia europeistyczne, „Studia Europejskie” 38 (2006), nr 2, s. 33-51.

4 K. Wielecki, European social order transformation....

5 Tamże. 
i powoli się rozwijają. Zwykle jest to proces, który zachodzi za pamięci wielu pokoleń.

Globalizacja, główny proces cywilizacyjny, powodujący wspomniane zmiany cywilizacyjne i naruszający podstawy równowagi ładu społecznego, jest zjawiskiem, które rozpoczęło się, orientacyjnie rzecz biorąc, w połowie lat 70. $\mathrm{xx}$ wieku, w wyniku skumulowania się wielu odkryć naukowych i technicznych oraz ich coraz bardziej stanowczego wdrażania do praktyki społeczeństwa przemysłowego. Nowe technologie, nie pierwszy raz w historii, zmieniły ludzki świat. $\mathrm{W}$ tym wypadku spowodowały schyłek, trwającej od osiemnastowiecznej rewolucji naukowo-technicznej, cywilizacji industrialnej. Jednym z ważnych efektów rozwoju praktyki nowej, informacyjnej cywilizacji było to, że świat staje się jednym organizmem ${ }^{6}$.

Bardzo istotnym tego przejawem jest tworzenie się zglobalizowanego rynku. Nowe technologie pozwalają na błyskawiczną komunikację praktycznie z każdym miejscem na świecie. Umożliwia to prowadzenie na bieżąco księgowości wielkich operacji finansowych dokonywanych na całym globie $\mathrm{z}$ dowolnego terytorium, przesyłanie kapitału w każdym momencie $z$ kontynentu na kontynent $\mathrm{w}$ czasie nie dłuższym, niż potrzeba, by dostarczyć go z jednej strony ulicy na drugą. Można też dziś skutecznie zarządzać procesami wytwarzania w wielu miejscach świata $\mathrm{z}$ jednego punktu sterowania gospodarczego. Organizacja zaopatrzenia, marketingu, obsługi finansowej, sieci dystrybucji, kredytowania itp. w sieci komputerowej, czyli w systemie obejmującym cały świat, nie jest dzisiaj niczym nadzwyczajnym.

Nowe technologie, a zwłaszcza zglobalizowana komunikacja, umożliwiają także tworzenie się wielkich organizacji światowych, swoim potencjałem ekonomicznym i obszarem działania przekraczających nie tylko potencjał poszczególnych państw, ale także kontynentów. Żadne państwo, poza największymi, nie jest w stanie poważnie przeciwstawić się wielkim korporacjom, które mogą w krótkim czasie spowodować lawinowy wzrost bezrobocia, wypływ kapitału doprowadzający do nagłego i rozsadzającego gospodarkę państwa kryzysu finansowego, i które mają nieograniczone możliwości nacisku na urzędników i parlamentarzystów.

6 Tamże. 
W ten sposób zmieniają się funkcje państw, z wszystkimi tego, niepoznanymi jeszcze w pełni, skutkami. Bodaj jedną z najważniejszych korekt kapitalizmu, jakie stały się wspomnianymi stabilizatorami po II wojnie światowej, świadczących chlubnie o zdolności wyciągania wniosków przez społeczeństwa kapitalistyczne, była regulacja „wolności” rynku przez państwo, które z klasowego stało się państwem obywatelskim ${ }^{7}$. Równowaga polityczna, gospodarcza i społeczna, jaką osiągnęły państwa, które wprowadziły u siebie ład demokratyczno-liberalny, dziś jest w stanie poważnego kryzysu. Po pierwsze, z powodu zmniejszającego się znaczenia pracobiorców na rynku. Po drugie zaś, z powodu koncentrowania się rynków ponadnarodowych, pozostających poza wpływem państw i ich polityki. Ziszcza się marzenie wielu o „wolnym” rynku, tym razem jednak nie narodowym, lecz globalnym. Skutkiem tego mogą być nowe migracje światowe, rewolucje, wojny, przede wszystkim terroryzm, o którym wiemy już, że nie ma dla niego barier, mimo nowoczesnych sposobów inwigilacji i środków pozostających do dyspozycji policji, wojska itp. Osobną kwestią jest potencjalna marginalizacja społeczna olbrzymich rzesz ludności, którą można rozpatrywać nie tylko w kategoriach racjonalności politycznej, gospodarczej i społecznej, ale także w kategoriach wartości moralnych. Zjawiska te już mają miejsce. Tym razem w skali globalnej.

Można mówić o specyficznej sekwencyjności kryzysu cywilizacyjnego: pojawiając się, uruchamia całe ciągi najrozmaitszych procesów przystosowawczych, ubocznych i przypadkowych, żywiołowych i nie. Kryzys cywilizacyjny wywołuje kryzys społeczny, powodując zaburzenia ładu społecznego. Pojęcie to odnoszę do organizmów społecznych, które dziś są instytucjonalizowane przede wszystkim w postaci państwa. Ład każdego z nich posiada swoją logikę i charakter. Jednakże rozmaite społeczności (państwa) mają często pewne istotne cechy wspólne, kształtują się pod wpływem tych samych wyzwań i wydarzeń cywilizacyjnych, we wspólnych lub podobnych realiach cywilizacyjnych. Ład społeczny to stale tworzony i odtwarzany wynik zmiennego, wewnętrznie niejednorodnego, złożonego i dynamicznego procesu strukturacji. Jest to proces krystalizowania się, reprodukowania, rozpadu i transformacji, relatywnie

7 Por. tenże, Globalisation and free market, „Yearbook of Polish European Studies Warsaw University Centre for Europe" 8 (2004), s. 165-186. 
stałych i względnie ciągłych podstaw organizowania się społecznej praktyki życia w obrębie względnie wyodrębnionej dużej społeczności. Tak pojmowany ład społeczny wyznacza mniej lub bardziej trwałe ramy wspólnej praktyki życia. Wyróżnimy w ładzie społecznym pięć wymiarów: strukturę społeczną (grupy, warstwy i klasy społeczne oraz system zależności między nimi), kulturę, ład instytucjonalny, ład gospodarczy i ład demograficzny.

W obrębie cywilizacji industrialnej powstał nowy typ ładu społecznego, który określam jako demokratyczno-liberalny ład społeczny oparty o prospołeczną gospodarką rynkową. Jednak od około połowy lat 70 . w przestrzeni społecznej coraz bardziej wyraźną rolę poczynają pełnić nowe technologie i ich wytwory. Spowodowały one także proces stopniowej i narastającej erozji ładu demokratyczno-liberalnego i podstaw gospodarki rynkowej, uruchamiając takie zjawiska jak np. finansjalizacja i kapitalizm kasynowy, narastające bezrobocie itd. Poważne zmiany zachodzą też na poziomie struktury społecznej (zanikanie niektórych warstw i klas, pojawianie się innych, zmiany układu sił). Towarzyszy temu marginalizacja ekonomiczna, kulturowa, społeczna i polityczna wielu ludzi oraz całych społeczności.

\section{Kontekst globalnego kryzysu gospodarczego ${ }^{8}$}

Od 2008 roku mamy do czynienia $z$ otwartą fazą kryzysu gospodarczego. Jedna z najwybitniejszych znawczyń gospodarki i współczesnego jej kryzysu, socjolog Saskia Sassen, pisała: „kapitalizm finansowy osiągnął właśnie granicę swojej logiki. Doszło do tego, ponieważ w dużej mierze spenetrował on już tak znakomitą część każdej z gospodarek narodowych, zwłaszcza w świecie wysokorozwiniętym, że te ich obszary, z których mógł wysysać kapitał niefinansowy, żeby samemu się ratować, stały się zbyt małe, by dostarczyć ilości kapitału wymaganej do udzielenia pomocy systemowi finansowemu. Dlaczego? Ponieważ globalna wartość aktywów finansowych (tzn. długu) na całym świecie we wrześniu 2008 r., kiedy to wybuchł kryzys, już ponad trzykrotnie (160 bilionów dolarów)

8 W tej części odwołuję się do: tenże, Wykluczenie, podwójna pętla transformacji i makrostrategia społeczno-gospodarcza. Przypadek polski na tle Unii Europejskiej, w: Wykluczenie społeczno-moralne, red. K. Kietliński, Warszawa 2014, s. 63-77. 
przekraczała wartość globalnego РКв. Nie da się uratować systemu finansowego, pompując w niego te pieniądze, którymi obecnie dysponujemy.

To z kolei uwypukla skrajne nadużycia wobec całych gospodarek, do jakich doszło wskutek ekspansji różnych form finansjeryzacji. Przykładowo, przed obecnym «kryzysem» wartość aktywów finansowych w UsA sięgała $450 \%$ PKB, a w Unii Europejskiej było to $356 \%$ РКв. Całkowita ich wartość np. w Niemczech wynosiła w październiku 2008 r. 9 bilionów dolarów, co jest kwotą porównywalną do РКв tego kraju. Ogólnie rzecz biorąc, liczba państw, w których wartość aktywów finansowych przekroczyła wartość produktu krajowego brutto, wzrosła ponad dwukrotnie, z 33 W 1990 r., do $72 \mathrm{w}$ roku 2006 "9.

Choroba nie tylko trawiła wielkie korporacje, ale - co jest ważne socjologicznie i ekonomicznie - dotykała też wyraźnie gospodarstw domowych i poszczególnych obywateli. W 1996 roku 56-60 mln amerykańskich gospodarstw domowych było zadłużonych na kartach kredytowych na ponad 6 tys. dolarów i płaciło 1 tys. dolarów odsetek i opłat. Typowe amerykańskie gospodarstwo domowe miało roczny dochód poniżej 20 tys. dolarów, a zadłużenie na karcie kredytowej - ponad 10 tys. dolarów ${ }^{10}$. W 1944 roku, w czasie II wojny światowej, oszczędności Amerykanów wynosiły 25,5\% dochodów netto (po opłaceniu podatków), na początku lat 90. $-6 \%$, a w 1998 roku wydatki były wyższe niż zarobki o $0,2 \%{ }^{11}$.

Inna sprawa, że dochody i zadłużenie nie rozkładają się równo. Rozwarstwienia społeczne są także ważnym kryterium analizy systemu gospodarczego i ładu społecznego. 90\% zysków z giełdy trafia w USA do 10\% najbogatszych gospodarstw domowych, a $60 \%$ rodzin nie ma żadnych akcji ${ }^{12}$. Jak na to wskazują przytoczone powyżej dane, kryzys gospodarczy zapowiadał się od dawana i jest bardzo głęboki. Prognozy zaś co do jego rozwoju są zmienne i bardzo niepewne. Rysunek 1 przedstawia oceny szans wzrostu gospodarczego na świecie. Dodajmy, że tego rodzaju dane zmieniają się i zwykle są zbyt optymistyczne.

\footnotetext{
9 S. Sassen, I tak skończy się świat, nie hukiem lecz szeptem..., „Le Monde Diplomatique” 37 (2009), $\mathrm{nr} 3$.

${ }^{10} \mathrm{~S}$. Brobeck, The consumer impacts of expanding credit cart debt, „Consumer Federation of America" (1997), nr 2, s. 1.

${ }^{11}$ J. Rifkin, Koniec pracy. Schyłek siły roboczej na świecie i początek ery postrynkowej, tłum. E. Kania, Wrocław 2003, s. 44.

${ }^{12}$ L. C. Thurow, Boom that wasn't, „New York Times” z 18 I 1999, s. A19.
} 


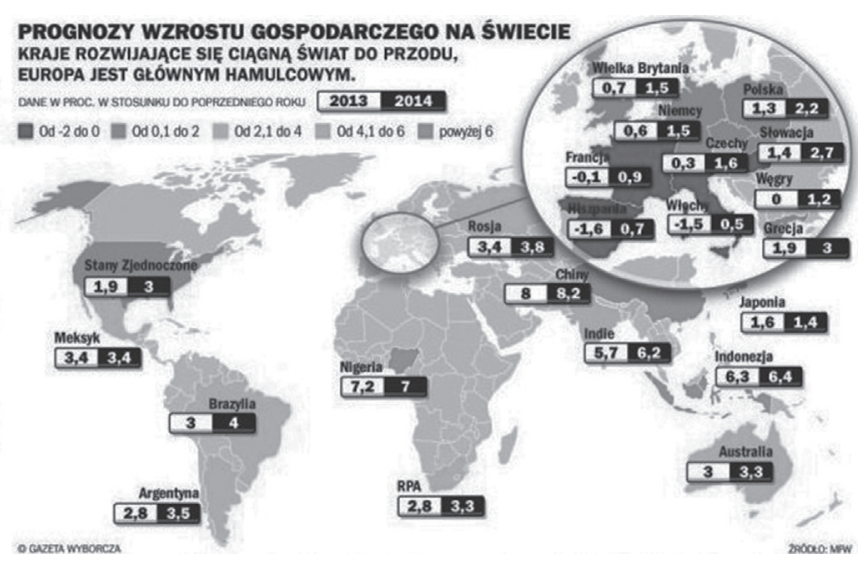

Rys. 1. Prognozy wzrostu gospodarczego na świecie ${ }^{13}$

Wydaje się, iż prognozy te są tym mniej optymistyczne, im bardziej rozwiniętej i nowoczesnej gospodarki dotyczą. Wyraźnie przewidywania wzrostu gospodarczego są najmniej obiecujące dla Europy. Są też skromne w odniesieniu do UsA.

Niestety, nie dość, że niepokojące dziś, to jeszcze mniej optymistyczne są te dane na przyszłość. Zła kondycja gospodarek państw bogatych będzie raczej powodować spowolnienie w państwach ubogich, a "renta” braku rozwoju cywilizacyjnego, która osłabia skutki lokalnego kryzysu na dłużej, nie będzie działać w globalizującym się świecie. Wzrost gospodarczy nie jest oczywiście wystarczającym wskaźnikiem pozwalającym oceniać perspektywy gospodarcze świata, ale jest wskaźnikiem wystarczająco syntetycznym, aby ukazać istotną tendencję.

\section{Dylematy polityki społecznej}

Naszkicowana tu (z konieczności bardzo skrótowo) sytuacja kryzysu cywilizacyjnego i, powodowanego przezeń, kryzysu gospodarczego, a nawet szerzej - kryzysu kapitalizmu, ukazuje najogólniejszą perspektywę polityki społecznej.

${ }^{13}$ Cyt. za: L. Baj, Europejska plama recesji na mapie świata, http://wyborcza.biz/biznes/1,100896,13749424,Europejska_plama_recesji_na_mapie_swiata.html (28.02.2016). 
Jeśli bowiem zgodzimy się, że „Współczesne państwo dźwiga główny ciężar przeciwdziałania powstawaniu i rozszerzaniu się grup marginalnych... W ostatecznym ujęciu ich [państwowych systemów zabezpieczenia społecznego] zadaniem jest zachowanie spokoju społecznego, a implicite przeciwdziałanie procesom społecznej marginalizacji” ${ }^{14}$, to przyznać trzeba, że polityka społeczna musiałaby graniczyć z cudem, w sytuacji słabnącego i ubożejącego państwa, przeciążonego skutkami globalnego kryzysu finansowego.

Jak powiada Julian Auleytner, polityka społeczna państwa to „działalność państwa, samorządów i organizacji pozarządowych, której celem jest poprawa położenia materialnego, asekuracja przed ryzykami życiowymi i wyrównywanie szans życiowych grup społeczeństwa ekonomicznie i socjalnie najsłabszych" ${ }^{\prime 1}$. Zapewne, ale jaka polityka jakiego państwa może sobie $\mathrm{z}$ takimi zadaniami poradzić?

Warto odnieść się jeszcze do zdania Edmunda Wnuk-Lipińskiego, który pisał: „Szeroko rozumiana polityka społeczna może być określona jako nieustanne, zorganizowane i świadome działanie nakierowane na utrzymywanie względnej równowagi między dwiema wartościami: wolnością i równością" ${ }^{16}$, instrumentem zaś do tego jest „proces redystrybucji dóbr i usług wedle pewnych normatywnych założeń" ${ }^{\prime 17}$. U wielu autorów, z Wnuk-Lipińskim i Tadeuszem Kowalakiem włącznie, mówi się zaś o wartościach jako o punkcie odniesienia.

Porównanie danych dotyczących produktu krajowego brutto w Unii Europejskiej w przeliczeniu na głowę mieszkańca w odniesieniu do średniej unijnej oraz wydajności pracy obliczanej per capita w relacji do średniej unijnej, a także nakłady na welfare state i wydatki na badania i rozwój jako procent РКв poszczególnych państw - może dostarczyć pouczających wniosków ${ }^{18}$. Przede wszystkim wynika z nich wyraźne wskazanie

${ }^{14}$ T. Kowalak, Polityka społeczna. Wybrane zagadnienia, Białystok 20oo, s. 9.

${ }_{15}$ J. Auleytner, Strategia polskiej polityki społecznej, w: Strategia rozwoju Polski do roku 2020, t. 2, Komitet Prognoz „Polska 200o Plus” przy Prezydium PAN, Warszawa 200o, s. 169.

${ }^{16}$ E. Wnuk-Lipiński, Demokratyczna rekonstrukcja. Z socjologii radykalnej zmiany spoŁecznej, Warszawa 1996, s. 62.

${ }_{17}$ Tamże.

${ }^{18}$ Szczupłość miejsca uniemożliwia przedstawienie tutaj tych danych w tabeli. Muszę zatem odesłać zainteresowanych do: K. Wielecki, Wykluczenie, podwójna pętla transformacji..., s. 75 . 
na istotność kapitału społecznego. Okazuje się też, że gospodarki charakteryzujące się dużymi nakładami na funkcje opiekuńcze oraz badania i rozwój mają także bardzo wysokie wskaźniki wydajności pracy. To zaś wpływa bardzo korzystnie na wysokość РКв. Oczywiście po takiej diagnozie natychmiast pojawia się pytanie, z jakich źródeł sfinansować wzrost nakładów na welfare state, zwłaszcza jeśli nie chce się pogłębiać i tak katastrofalnej, lokalnej i globalnej bańki finansowej. Jest też pewne, że wydatki na państwo opiekuńcze muszą mieć charakter przemyślanych inwestycji w kapitał społeczny, a nie bezrefleksyjnego rozdawnictwa. Miałyby one zaradzać kryzysowi, a nie pogłębiać go. Jest to zatem pytanie o politykę społeczną.

Współczesny kryzys finansowy jest wynikiem długotrwałego, systemowego kryzysu gospodarczego, a w gruncie rzeczy załamania się pewnej ideologii i praktyki ekonomicznej, jaka dominowała w ostatnich trzech dziesięcioleciach. Być może za pomocą prostych metod uda się na jakiś czas poprawić sytuację gospodarczą na świecie lub wykonać kilka operacji mogących odroczyć ostateczną katastrofę. Jednak to nie rozwiąże problemu wielkiego kryzysu cywilizacyjnego. Jedynym wyjściem jest wybór scenariusza „poślizgu kontrolowanego”, skoro w ogóle poślizgu uniknąć się nie da. Wymaga to jednak spojrzenia prawdzie w oczy i zrozumienia istoty współczesnego kryzysu, a na to niestety się nie zanosi.

Jedną z najciekawszych propozycji polityki społecznej, a przede wszystkim mocno osadzoną w realiach zmieniającego się świata, stworzył Anthony Giddens. Jej pierwszy wykład znajdujemy w Trzeciej drodze $e^{19}$. Potem zaś ukazał się tom pt. Runway world ${ }^{20}$, bardziej popularna wersja poprzedniego dzieła, następnie książka The third way and its critics ${ }^{21}$, zawierająca szerszą dyskusję wokół tez Giddensa, a w końcu ukazuje się The global third way debate ${ }^{22}$, rzecz redagowana przez Giddensa, zamykająca całość debaty. Tak więc w ciągu czterech lat w środowisku socjologicznym koncepcja brytyjskiego uczonego wywołała spore poruszenie oraz rozmaite próby diagnozy i prognozy zmieniającego się

\footnotetext{
19 A. Giddens, Trzecia droga. Odnowa socjaldemokracji, tłum. H. Jankowska, Warszawa 1998.

${ }_{20}$ Tenże, Runaway world. How globalization is reshaping our lives, New York 2000.

${ }^{21}$ Tenże, The third way and its critics, Malden 2000.

${ }^{22}$ Tenże, The global third way debate, Cambridge-Malden 2001.
} 
i „uciekającego” świata. Rola autora jako doradcy Tony'ego Blaira oraz Billa Clintona z pewnością wpłynęła na obecność w tej dyskusji wątku politycznego. Zamiarem zresztą Giddensa było intelektualne wsparcie brytyjskiej Partii Pracy. Stąd tak wyraźny we wspomnianych publikacjach wątek polityki społecznej, pojmowanej w sposób bardzo fundamentalny, jako próba łączenia najgłębszego namysłu nad najistotniejszymi procesami współczesnego świata, ujmowanymi w sposób holistyczny, integralny i interdyscyplinarny, z wymiarem praktycznym, czyli właśnie polityki społecznej.

Głos Giddensa jest interesujący również z tego względu, iż lewica, w imieniu której występował, pomawiała go potem o zdradę i przejście na stronę prawicy i liberalizmu, prawica zaś krytykowała go jako lewaka. Sam autor pisał w przedmowie do Trzeciej drogi: „ta niewielka książka ma być moim wkładem w toczącą się w wielu krajach dyskusję o przyszłości polityki socjaldemokracji. Powody, dla których wszczęto tę debatę, są dość oczywiste: zanik konsensu na rzecz dobrobytu, który dominował w państwach przemysłowych jeszcze do końca lat siedemdziesiątych, ostateczna kompromitacja marksizmu oraz przyczyniające się do tych zjawisk niezwykle głębokie przemiany społeczne, gospodarcze i technologiczne. Mniej oczywiste jest, co należałoby w tej sytuacji robić [...]"23. Anthony Giddens podzielał w Trzeciej drodze pogląd o szczególności czasów i zamęcie, jaki je charakteryzuje. Uznał jednak, iż miast się na nie obrażać, trzeba je zrozumieć, zrewidować cele, aby uchronić wartości. Co więcej, był zdania, iż można wykorzystać logikę głównych procesów późnej nowoczesności, aby te wartości urzeczywistniać jeszcze lepiej. Zamienić kłopoty na sukces, to - jak się wydaje - główna idea brytyjskiego socjologa. Pisał np.: „Przeciwstawienie się rynkowemu fundamentalizmowi w skali jednego kraju i dopuszczanie, by rządził w wymiarze globalnym, jest pozbawione sensu" ${ }^{24}$. Ale proponował politykę kosmopolitycznej demokracji, która miałaby złu zaradzić25. Sięgał do korzeni polityki społecznej, wersji skandynawskiej odmiany welfare state, ale rozumiał jej słabości, zwłaszcza tam, gdzie protestancka z ducha kultura nie łagodziła wszelkich jej dysfunkcjonalności. Uznał, iż polityka społeczna

\footnotetext{
${ }^{23}$ Tenże, Trzecia droga..., s. 7.

${ }^{24}$ Tamże, s. 128.

${ }_{25}$ Tamże.
} 
winna stać się w tych trudnych czasach stymulatorem wzrostu gospodarczego, instrumentem wspierania nowoczesnego kapitalizmu, a podział dochodu nie może paraliżować zaradności, energii i pomysłowości pracobiorców ani odbierać wiatru z żagli pracodawcom. Opinia Giddensa w jednej z najistotniejszych spraw, być może kluczowej dla gospodarki i demokracji, jaką jest model kapitalizmu, była jednak pesymistyczna.

Zauważmy, że we współczesnej gospodarce wyraźnie wyłaniają się dwie orientacje. Pierwszą jest kapitalizm bezwzględny, nastawiony wyłącznie na akumulację kapitału, bez skrupułów wykorzystujący sieć, aby ominąć jakiekolwiek zobowiązania wobec człowieka, kultury, środowiska naturalnego itp. Opiera się na anonimowym akcjonariacie, wirtualnym pieniądzu, którego właściciele nie zamierzają się z kimkolwiek lub czymkolwiek utożsamiać, solidaryzować lub komukolwiek współczuć. Kapitalizm taki bez żenady niszczy ludzi, środowisko i kulturę. Jego zwolennicy, posługując się ideologią neoliberalnej wolności, monopolizują rynek, niszczą konkurencję. Drugą orientacją jest kapitalizm o bardziej korporacyjnym nastawieniu (zapewne najbardziej zaawansowany w Szwecji), występujący między innymi w postaci ruchów społecznych lub wspólnot. Zysk, choć bardzo ważny, nie jest dla niego jedynym dobrem, a proces decyzyjny i redystrybucja zysku mają często cele społeczne lub wręcz ekologiczne. Wydaje się jednak, iż procesy globalizacji bardziej sprzyjają temu pierwszemu rodzajowi kapitalizmu.

\section{Punkt podparcia w myśli Jana Pawła II}

Okazuje się, że analiza współczesnej praktyki gospodarczej doprowadza nas z powrotem do myśli Wnuk-Lipińskiego, który - jak to wyjaśniałem powyżej - wiązał politykę społeczną z wartościami. Te zaś łączą się jawnie z konceptami człowieka, dobra i zła, „dobrego społeczeństwa”, przekonaniami o naturze ludzkiej itp. Tym zagadnieniom poświecona jest ostatnia część niniejszego artykułu. Nie ma tu miejsca na szerokie studia tego rodzaju. Świadomie i - jak wierzę - z pożytkiem dla problemu zawężam obszar penetracji na potrzeby tego artykułu. Szukam mianowicie punktu odniesienia i podparcia dla koncepcji polityki społecznej w myśli Jana Pawła II. Naturalnie, ambicja wyczerpania tego wątku przekraczałaby objętość kilku książek. Ja jedynie chcę wskazać na najistotniejsze - moim zdaniem - tropy, które mogłyby nas doprowadzić do istoty rzeczy. 
Jest oczywiste, iż te dwie wizje gospodarki, jakie wyprowadziłem powyżej z analizy współczesności, zakorzenione są w dwóch różnych systemach wartości. Pierwsza jest stricte neoliberalna. Co do drugiej zaś warto na ten temat podjąć dyskusję. Z całą pewnością model skandynawski jest z natury socjaldemokratyczny. Potwierdza to twórczość wspomnianego Giddensa, ale wyraźne odniesienia możemy znaleźć też w pisarstwie Jürgena Habermasa i wielu innych socjologów, otwarcie przyporządkowujących się do socjaldemokratycznych korzeni.

Jednak podobne sympatie możemy znaleźć u wielu katolickich filozofów, socjologów czy ekonomistów. Wyraźne inspiracje dla polityki welfare state odkrywamy w koncepcjach takich ojców założycieli integrującej się Europy, jak np. Robert Schuman czy Alcide De Gasperi ${ }^{26}$. Dzisiaj zaś ów koncept gospodarczy znajduje wsparcie u papieża Franciszka, zwłaszcza w jego encyklice Laudato si’. Szczególnie, gdy Ojciec święty wypowiada się na temat dzisiejszej gospodarki: „Paradygmat technokratyczny dąży do objęcia swoim panowaniem także gospodarki i polityki. Gospodarka postrzega wszelki rozwój technologiczny w zależności od zysku, nie zwracając uwagi na jakiekolwiek ewentualne negatywne skutki dla człowieka. Finanse tłumią ekonomię realną. Nie wyciągnęliśmy wniosków z globalnego kryzysu finansowego i bardzo powoli pobieramy naukę z degradacji środowiska naturalnego" ${ }^{27}$. Ale podobne idee możemy znaleźć u Jana xxiII, zwłaszcza w jego encyklice Pacem in terris czy też Mater et magistra. Jednak w tym artykule odwołam się do myśli Jana Pawła II.

Podobieństwa katolickiej i socjaldemokratycznej wizji dobrej gospodarki mogą występować na poziomie diagnoz. Jeśli obiektywny osąd może prowadzić tylko do jednej prawdy, to nie ma się czemu dziwić. Mogą też występować zbieżności dotyczące konkretnych rozwiązań lub ocen. Istotna różnica tkwi natomiast na poziomie wartości i źródeł, z których się je wyprowadza. Dla socjaldemokratów racją zasadniczą jest wartość równości i sprawiedliwości społecznej, ewentualnie dobro klasy społecznej, zaś dla katolickich koncepcji - wola Boża i miłość. Jak pisał Jan Paweł II: „W Piśmie Świętym znaleźć można cały zespół elementów, dostępnych bezpośrednio lub pośrednio, które pozwalają zbudować wizje

\footnotetext{
${ }^{26} \mathrm{~K}$. Wielecki, Alpinizm bez asekuracji, czyli Unia wobec zmiany cywilizacyjnej, „Chrześcijaństwo - Świat - Polityka. Zeszyty Społecznej Myśli Kościoła” (2014/2015), nr 17/18, s. 51-6o.

${ }^{27}$ LS 109.
} 
człowieka i świata o znacznej wartości filozoficznej [...] Tylko Bóg jest absolutem. Ze stronic Biblii wyłania się ponadto wizja człowieka jako imago Dei, która zawiera konkretne wskazania dotyczące jego istoty i wolności oraz nieśmiertelnego ducha” ${ }^{” 2}$. I jeszcze: „Człowiek nie może żyć bez miłości. Człowiek pozostaje dla siebie istotą niezrozumiałą, jego życie jest pozbawione sensu, jeśli nie objawi mu się Miłość, jeśli nie spotka się z Miłością, jeśli jej nie dotknie i nie uczyni w jakiś sposób swoją, jeśli nie znajdzie w niej żywego uczestnictwa"29.

W myśli Karola Wojtyły pojęcie człowieka nabiera sensu dopiero z perspektywy wolności osoby ludzkiej odniesionej do Boga. Punktem wyjścia do myślenia o człowieku może być tu fenomenologiczne odkrycie doświadczenia: „mogę - nie muszę - chcę”. Tu ujawnia się sprawczość człowieka $^{30}$, pojawia się problem jego podmiotowości i wolności. Wolność bowiem jest cechą w sposób szczególny charakteryzującą człowieka. Podstawowe dla podmiotowości osoby ludzkiej są też rozumność i duchowość. Duchowość oznacza zaś życie wewnętrzne, dla którego centrum stanowią prawda i dobro. To wyznacza dwie centralne orientacje człowieka: nakierowaną na rozumienie ostatecznej przyczyny wszystkiego oraz nakierowaną na dobro. Człowiek jednak jest nie tylko duchowy, ale też należy do świata zewnętrznego. Pragnie w nim zaznaczyć siebie, gdyż tego żąda od niego jego natura. Natura ta daje mu także władzę samostanowienia, czyli wolną wolę ${ }^{31}$.

Podmiotowość, rozumiana jako samostanowienie, nie jest po prostu wolnością spełniania woli. Warunkiem jest samo-posiadanie, czyli bycie osobą sui iuris, które umożliwia samo-panowanie. Wola transcenduje osobę w czynie.

Dochodzimy tu do drugiego, podstawowej natury dla tych rozważań, doświadczenia - fenomenologicznej oczywistości wstydu, jako czegoś, co odsyła nas do czegoś jeszcze innego, a co z kolei kieruje nas do transcendentnej wartości osoby ludzkiej ${ }^{32}$. Powróćmy do triady „mogę - nie muszę - chcę", w której ujawnia się horyzont wolności człowieka, który

\footnotetext{
${ }^{28}$ FR 8 O.

${ }^{29} \mathrm{RH} 3 \mathrm{O}$.

${ }^{30}$ K. Wojtyła, Osoba i czyn, Lublin 1994, s. 151.

${ }^{31}$ Tenże, Miłość i odpowiedzialność, Lublin 1986, s. 9-10.

${ }^{32}$ Tamże, cz. 3.
} 
wszak nie musi, dla którego inklinacja nie jest determinacją, który może wybierać, jak chce. W ten sposób podmiot jest wplątany w etykę, gdyż często wybór dotyczy w istocie dobra lub zła. Zdaniem Wojtyły wolnym, w sensie wolności od determinizmu, czyni nas posłuszeństwo wobec prawdy ${ }^{33}$.

Osoba jest substancją, ale też relacją. Zwłaszcza chodzi tu o relację do drugiego człowieka. Jak pisze Zofia Zdybicka: „Podstawowym źródłem refleksji filozoficznej Wojtyły było doświadczenie człowieka: bezpośrednie, przedmiotowe, rozumiejące. Człowiek może doświadczać siebie, swego wnętrza, dzięki refleksji towarzyszącej każdemu działaniu (czynowi). Refleksyjna analiza ludzkiego działania, doświadczenie rozumiejące, prowadzi do odkrycia podmiotu - sprawcy działania i tego, kto przeżywa swoją podmiotowość - a więc do odkrycia osoby"34. Od sposobu, w jaki wchodzimy w te relacje, zależy nasza podmiotowość, czyli to, czy uda się nam doprowadzić swą ludzką istotę do pełni bytowości. Widzimy, że podmiotowość jest zadaniem, wyzwaniem spełnienia potencji, którą jako ludzie posiadamy. Warunkiem jest, by drugiego traktować nieinstrumentalnie, gdyż w przeciwnym razie osoba traci godność, jaka wiąże się z tym, że człowiek jest dzieckiem Bożym. Być w pełni sobą, a więc naprawdę podmiotowym, można przede wszystkim w spotkaniu z Jezusem Chrystusem, w którym Bóg objawia samego siebie i prawdę o człowieku. Jedynym podmiotowym rodzajem relacji w odpowiedzi na tę godność, jaką człowiek otrzymał jako łaskę, jest miłość. Miłość, która jest nie tyle emocją, co wyborem, wolą, dla której wzorem jest Chrystus na krzyżu. Tu leży powód, dla którego podmiotowość jest posłuszeństwem prawdzie i miłości, na wzór Jezusa Chrystusa, który wszak służył Bogu i ludziom. Ten rodzaj komunii, która w miłości łączy Boga z człowiekiem, powinien być naśladowany w czynach, jakie ludzie spełniają w relacjach między sobą. To tylko przez czyny tak pojmowanej miłości wobec innych ludzi, zakorzenionej w miłości do Boga, możliwa jest podmiotowość człowieka ${ }^{35}$.

33 Tenże, Osoba i czyn, s. $150 \mathrm{nn}$.

${ }^{34}$ Z. Zdybicka, Karol Wojtyła, hasło w: Powszechna encyklopedia filozofii, t. 9, red. A. Maryniarczyk, Lublin 2008.

${ }^{35}$ K. Wojtyła, Osoba i czyn, cz. II i Iv. 
Swoboda ekonomiczna człowieka musi zatem podlegać samoograniczaniu się. Czytamy: „Rozwój techniki oraz naznaczony panowaniem techniki rozwój cywilizacji współczesnej domaga się proporcjonalnego rozwoju moralności i etyki. Tymczasem ten drugi zdaje się, niestety, wciąż pozostawać w tyle. I stąd też ów skądinąd zdumiewający postęp, w którym trudno nie dostrzegać również tych rzeczywistych znamion wielkości człowieka, jakie w swych twórczych zalążkach objawiły się na kartach Księgi Rodzaju już w opisie jego stworzenia (por. Rdz 1-2), musi rodzić wielorakie niepokoje. Niepokój zaś dotyczy zasadniczej i podstawowej sprawy: czy ów postęp, którego autorem i sprawcą jest człowiek, czyni życie ludzkie na ziemi pod każdym względem «bardziej ludzkim», bardziej "godnym człowieka»? Nie można żywić wątpliwości, że pod wielu względami czyni je takim. Pytanie jednak, które uporczywie powraca, dotyczy tego, co najistotniejsze: czy człowiek jako człowiek w kontekście tego postępu staje się lepszy, duchowo dojrzalszy, bardziej świadomy godności swego człowieczeństwa, bardziej odpowiedzialny, bardziej otwarty na drugich, zwłaszcza dla potrzebujących, dla słabszych, bardziej gotowy świadczyć i nieść pomoc wszystkim?"36.

Model gospodarczy musi spełnić kilka poważnych warunków, aby mógł być zaakceptowany przez katolika. Nie każdy kapitalizm jest zatem moralnie czysty. Godny polecenia będzie taki jego model, który zniesie rywalizację między kapitałem i człowiekiem pracującym. Czytamy: „słusznym, to znaczy wewnętrznie prawdziwym i zarazem moralnie godziwym może być taki ustrój pracy, który u samych podstaw przezwycięża antynomie pracy i kapitału, starając się kształtować [...] wedle przedstawionej powyżej zasady merytorycznego i faktycznego pierwszeństwa pracy, podmiotowości ludzkiej pracy oraz jej sprawczego udziału w całym procesie produkcji, i to bez względu na charakter wykonywanych przez pracownika zadań. [...] Jeśli w procesie pracy odkrywa się jakąś zależność - tu jest to zależność od Dawcy wszystkich zasobów stworzenia, a z kolei zależność od innych ludzi - tych, których pracy i inicjatywom zawdzięczamy poszerzone i ulepszone możliwości swojej pracy. Natomiast o wszystkim tym, co w procesie produkcji stanowi zespół «rzeczy», instrumentów, kapitału, możemy tylko twierdzić, że warunkuje pracę

${ }^{36} \mathrm{RH} 15$. 
człowieka, nie możemy natomiast powiedzieć, że stanowi jakby anonimowy «podmiot» uzależniający człowieka i jego pracę"37.

Polityka społeczna musi mieć zatem w centrum uwagi kwestie godziwości, uczciwości i sprawiedliwości. Czytamy: „zaangażowanie Kościoła w kwestii społecznej, odpowiada ściśle rozpoznaniu obiektywnego stanu rzeczy. Jeśli w przeszłości w centrum tej kwestii ujawniał się przede wszystkim problem «klasowy», to w ostatnim okresie na plan pierwszy wysuwa się problem «światowy». A więc nie tylko klasowy, ale światowy rozmiar nierówności i niesprawiedliwości, a w konsekwencji nie tylko klasowy, ale światowy rozmiar zadań na drodze do realizacji sprawiedliwości w świecie współczesnym. Wszechstronna analiza sytuacji świata współczesnego ujawniła głębsze i pełniejsze znaczenie, jakie należy nadać wysiłkom zmierzającym do budowania sprawiedliwości na ziemi, niż dawniejsza analiza struktur niesprawiedliwości społecznej, nie przesłaniając przez to owych struktur, lecz postulując rozpatrywanie ich i przeobrażanie w bardziej uniwersalnym wymiarze" ${ }^{38}$.

Jan Paweł II uważa się w tej materii za kontynuatora swoich wielkich poprzedników. „Encyklika Populorum proqressio jest jakby odpowiedzią na soborowy apel, od którego rozpoczyna się Konstytucja Gaudium et spes: «radość i nadzieja, smutek i trwoga ludzi współczesnych, zwłaszcza ubogich i wszystkich cierpiących, są też radością i nadzieją uczniów Chrystusowych; i nie ma nic prawdziwie ludzkiego, co nie miałoby oddźwięku w ich sercu». Słowa te wyrażają podstawowy motyw, który był natchnieniem dla wielkiego dokumentu soborowego, wychodzącego od stwierdzenia sytuacji nędzy i niedorozwoju, w jakiej żyje wiele milionów ludzkich istnień. Ta nędza i niedorozwój mają inne miano: «smutek i trwoga» w naszych czasach, zwłaszcza ludzi ubogich. W obliczu rozległej panoramy bólu i cierpienia Sobór pragnie ukazać horyzonty radości i nadziei. Do tego samego celu zmierza wierna soborowemu natchnieniu Encyklika Pawła vi"39.

Jan Paweł II uwzględnia zarówno współczesny, wspominany we wcześniejszych częściach tego artykułu, globalny wymiar zadań dla polityki

\footnotetext{
37 LE 13; por. CA 4, 6 i 8.

${ }^{38}$ LE 2.

39 SRs 6. Jan Paweł II powołuje się tu na encyklikę Populorum progressio oraz konstytucję soborową Gaudium et spes.
} 
społecznej, jak i ten, który leży w zakresie kompetencji społecznej polityki państwa. Czytamy mianowicie o jednym z najbardziej dramatycznych procesów współczesnego świata, który od czasów Jana Pawła II raczej się nasilił, niż osłabł; chodzi o „utrzymywanie się, a często powiększanie, przedziału pomiędzy obszarem tak zwanej rozwiniętej Północy a obszarem Południa, będącego na drodze rozwoju"40. Ale jak wyjaśnia sam Ojciec święty: „Ta terminologia geograficzna jest tyko umowna, gdyż nie wolno zapominać, że granice między bogactwem i ubóstwem przebiegają wewnątrz tych samych społeczeństw, zarówno rozwiniętych, jak na drodze rozwoju. Tak więc, jak w krajach bogatych istnieją nierówności społeczne aż do granicy nędzy, tak - równolegle w krajach słabiej rozwiniętych nierzadko widzi się przejawy egoizmu i wystawnego bogactwa, które budzi niepokój i zgorszenie. Obfitości dóbr i dostępnych usług w niektórych częściach świata, przede wszystkim w rozwiniętej Północy, odpowiada na Południu niedopuszczalne zacofanie, a właśnie w tej strefie geopolitycznej żyje większa część rodzaju ludzkiego" ${ }^{41}$.

W tym artykule pozostaję świadomie na bardzo wysokim stopniu ogólności. Lektura encyklik Jana Pawła II, jak również jego prac filozoficznych pozwala zakreślić dość szeroką przestrzeń problemów i punktów węzłowych. Ja jednak próbuję tu odpowiedzieć na pytanie o główne dylematy polityki społecznej czasu dramatycznego przełomu cywilizacyjnego. Zdaniem Ojca świętego istotny wymiar tego dylematu to problem rozwoju gospodarczego i wszelkiego innego. Pisał papież: „Krótko mówiąc, niedorozwój, którego świadkami jesteśmy w naszych czasach, nie jest jedynie niedorozwojem ekonomicznym, ale także kulturowym, politycznym i po prostu ludzkim, na co zwróciła już uwagę dwadzieścia lat temu Encyklika Populorum progressio. A zatem w tym punkcie należałoby zadać sobie pytanie, czy tak smutna dzisiejsza rzeczywistość nie jest, przynajmniej częściowo, wynikiem zbyt ograniczonej, to znaczy przede wszystkim ekonomicznej koncepcji rozwoju" ${ }^{42}$.

\footnotetext{
40 SRS 14.

41 Tamże.

${ }^{42}$ SRS 15.
} 


\section{Zakończenie}

Podstawowym zadaniem tego szkicu była analiza głównych wyzwań czasu kryzysu cywilizacyjnego, a następnie zastanowienie się nad współczesnym, wyznaczanym owym kryzysem, sensem polityki społecznej. Wspomniałem o dwóch modelach kapitalizmu, jakie wyłaniają się z tego trudnego czasu przełomu cywilizacji. Poszedłem tropem jednego z nich, moim zdaniem dającego szansę na adekwatną do współczesnych wyzwań politykę społeczną, który mimo pewnych podobieństw charakteryzuje się też poważnymi różnicami. Jego odmianę socjaldemokratyczną naszkicowałem, odnosząc się do koncepcji Anthony'ego Giddensa. Jednak wizja socjaldemokratyczna ma - moim zdaniem - pewną wadę podstawową, która w zmiennych kolejach historii może prowadzić politykę społeczną na manowce. Drugą odmianą tej koncepcji modelu gospodarki i zadań polityki społecznej, jakie z niej wynikają, jest katolicki punkt widzenia. Przedstawiłem tu przede wszystkim szkic poglądów Jana Pawła II, aby ukazać istotę tej różnicy. Wydaje mi się, że jest ona koniecznym horyzontem dla współczesnego myślenia o polityce społecznej, dziś może jeszcze bardziej dramatycznie niezbędnym niż w czasach, w których Jan Paweł II (a wcześniej Karol Wojtyła) pisał o tym. Starałem się, w formie - z konieczności - bardzo skrótowej, wykazać pożytki studiów dzieła naszego papieża, jak i całego nauczania Kościoła, z obecnym przesłaniem Ojca świętego Franciszka, jako warunku koniecznego mądrze ugruntowanej polityki społecznej.

\section{Bibliografia}

Auleytner J., Strategia polskiej polityki społecznej, w: Strategia rozwoju Polski do roku 2020, t. 2, Komitet Prognoz „Polska 2000 Plus” przy Prezydium Pan, Dom Wydawniczy „Elipsa”, Warszawa 2000.

Baj L., Europejska plama recesji na mapie świata, http://wyborcza.biz/biznes/1,100896,13749424,Europejska_plama_recesji_na_mapie_swiata.html (28.02.2016).

Balcerowicz L., O rzekomych obrońcach ludu, „Życie” z 19 I 2002.

Brobeck S., The consumer impacts of expanding credit cart debt, „Consumer Federation of America" (1997), $\mathrm{nr} 2$.

Esping-Andersen G., Social foundations of postindustrial economies, Oxford University Press, Oxford-New York 1999. 
Esping-Andersen G., Welfare states and the economy, w: The handbook of economic sociology, eds. N. J. Smelser, R. Swedberg, Princeton University Press Russel Sage Foundation, Princeton-New York 1994.

Franciszek, Encyklika Laudato si', Libreria Editrice Vaticana, Watykan 2015.

Giddens A., Runaway world. How globalization is reshaping our lives, Routledge, New York 2000.

Giddens A., The global third way debate, Polity Press - Blackwell Publishers, Cambridge-Malden 2001.

Giddens A., The third way and its critics, Polity Press, Malden 2000.

Giddens A., Trzecia droga. Odnowa socjaldemokracji, tłum. H. Jankowska, Książka i Wiedza, Warszawa 1999 [oryginał: The third way. The renewal of social democracy, Polity Press - Blackwell Publisher, Cambridge-Malden 1998].

Jan Paweł II, Encyklika Centesimus annus, przedruk: Libreria Editrice Vaticana, Włocławek 1991.

Jan Paweł II, Encyklika Fides et ratio, Libreria Editrice Vaticana, Watykan 1998. Jan Paweł II, Encyklika Laborem exercens, Wydawnictwo Ośrodka Dokumentacji i Studiów Społecznych, Warszawa 1982.

Jan Paweł II, Encyklika Redemptor hominis, Pallottinum, Poznań 1979.

Jan Paweł II, Encyklika Sollicitudo rei socialis, Ośrodek Chrześcijańskiej Myśli Społecznej Augustinum, Warszawa 1988.

Kowalak T., Polityka społeczna. Wybrane zagadnienia, Wyższa Szkoła Ekonomiczna, Białystok 2000.

Rifkin J., Koniec pracy. Schyłek sity roboczej na świecie i początek ery postrynkowej, tłum. E. Kania, Wrocław 2003.

Sassen S., I tak skończy się świat, nie hukiem lecz szeptem..., „Le Monde Diplomatique" 37 (2009), nr 3.

Thurow L. C., Boom that wasn't, „New York Times” z 18 I 1999.

Wielecki K., Alpinizm bez asekuracji, czyli Unia wobec zmiany cywilizacyj-

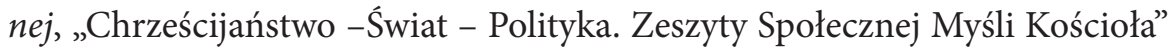
(2014/2015), nr 17/18, s. 51-6o.

Wielecki K., European social order transformation, mass culture and social marginalisation processes, „Yearbook of Polish European Studies Warsaw University Centre for Europe" 9 (2005), s. 115-133.

Wielecki K., Globalisation and free market, „Yearbook of Polish European Studies Warsaw University Centre for Europe” 8 (2004), s. 165-186.

Wielecki K., Społeczne aspekty kultury masowej. Studia europeistyczne, „Studia Europejskie" 38 (2006), nr 2, s. 33-51. 
Wielecki K., Wykluczenie, podwójna pętla transformacji i makrostrategia społeczno-gospodarcza. Przypadek polski na tle Unii Europejskiej, w: Wykluczenie społeczno-moralne, red. K. Kietliński, Warszawa 2014, s. 63-77.

Wnuk-Lipiński E., Demokratyczna rekonstrukcja. Z socjologii radykalnej zmiany społecznej, Wydawnictwo Naukowe Pwn, Warszawa 1996.

Wojtyła K., Miłość i odpowiedzialność, Wydawnictwo Towarzystwa Naukowego KUL, Lublin 1986.

Wojtyła K., Osoba i czyn, Towarzystwo Naukowe KuL, Lublin 1994.

Zdybicka Z., Karol Wojtyła, hasło w: Powszechna encyklopedia filozofii, t. 9, red. A. Maryniarczyk, Polskie Towarzystwo Tomasza z Akwinu, Lublin 2008.

\section{Abstrakt}

Celem tego artykułu jest nakreślenie, wstępny szkic, głównych problemów i hipotez oraz wstępne uporządkowanie zakresu tematycznego oraz „materiału” faktograficznego i głównych teorii, jakie mogłyby być dobrym początkiem pracy o koncepcji polityki społecznej we współczesnym świecie, inspirowanej myślą Jana Pawła II.

Wspomniany współczesny świat jest tu ujmowany w kategoriach kryzysu cywilizacyjnego, któremu poświęcam nieco miejsca. Punktem wyjścia jest szczególna teoria Anthony’ego Giddensa, który - gdy chodzi o politykę społeczną - próbował budować most między konceptem socjaldemokratycznym i neoliberalnym. Jednak rozwijam tu także tezę, iż kryzys cywilizacyjny jest zarazem przełomowy dla kultury i gospodarki. Jest to także kryzys człowieka. Zatem pomocy szukać trzeba w teorii człowieka, w antropologii filozoficznej i myśli społecznej. W tym artykule rozważam pożytki, moim zdaniem niekwestionowalne, $\mathrm{z}$ inspiracji myślą Jana Pawła II. Sądzę, a staram się to wykazać w tekście, iż nowoczesne pojmowanie polityki społecznej wymaga zrozumienia wyzwań, jakie w czasach kryzysu cywilizacyjnego stawiają człowiek, gospodarka i kultura.

W obliczu kryzysu cywilizacyjnego, z jego gigantyczną „bańką spekulacyjną”, polityka społeczna to także kwestia przemyślanych inwestycji w kapitał społeczny, a nie bezrefleksyjnego rozdawnictwa. Miałyby one zaradzać kryzysowi, a nie pogłębiać go. Jest to zatem pytanie o współczesną politykę społeczną, ale też o ów kapitał społeczny, racjonalność i kontekst wartości dla tej racjonalności. 
The ideas of John Paul II in the context of social policy in the postindustrial era

\begin{abstract}
The purpose of this article is to put forward an initial sketch, the main problems and hypotheses and an initial arrangement of the subjects and the factual „material" and major theories that could be a good beginning of a paper on the concept of social policy in the modern world, inspired by the ideas of John Paul II. The modern world is seen here in terms of a crisis of civilization, to which I devote some space. The starting point is the special theory of Anthony Giddens, who tried to build a bridge between social democratic and neo-liberal concept in the area of social policy.

However, also I elaborate upon the thesis that this crisis of civilization is a turning point for both culture and the economy. It is also a crisis of humankind. Therefore help should be sought in the theory of humankind in philosophical anthropology and social thought. In this article, I consider the benefits, which are in my opinion unquestionable, of drawing inspiration from the thinking of John Paul II. I believe that a modern understanding of social policy requires an understanding of the challenges which man, economy and culture pose in these times of civilization crisis, and I try to demonstrate this in the text

In the face of this crisis of civilization, with its gigantic „speculative bubble”, social policy is also about smart investments in social capital, not mindless handouts. These would remedy the crisis, not deepen it. This is therefore a question about a modern social policy, but also about this social capital, rationality and the context of values for this rationality.
\end{abstract}

